\title{
Unequal Education, Unequal Citizen? A Comparative Perspective on Equality in Education
}

\begin{abstract}
Chun-Hung Chen
Soochow University

Education has enormous influence on individual prospects for a flourishing life, thus, the justice of an education system is a key indicator of the justice in a society. Normally, the debate over educational justice refers to two fundamental questions: the conception of justice and the aims and purposes of education. We may agree about the meaning of justice, but disagree about the aim of education, and vice versa, and thus come to very different perspective about what educational policies should entail. However, what does justice look like when it comes to the distribution of educational goods? Should we ensure that all children have equal educational resources and opportunities or should we rather concentrate on equal educational attachment? Recently, there is a debate on educational justice which mainly focuses on the status and role of comparatively considerations within a just distribution of educational benefits. According to the adequacy approach, the state is required to ensure all children have enough or adequate education. Once the adequate threshold of educational resources is obtained, there is no injustice in the fact that some children have better education than others. In contrast with adequacy approach, proponents of what can be called educational equality approach have instead argued that justice requires prospects for educational achievement to be dependent upon a child's ability and willingness to learn, and not on factors outside of her control. Therefore, the state is required to ensure that an individual's prospects for educational achievement should be a function only of that individual's effort and talent, not of his or her social class background or other factors outside of her control. It seems that the debate between proponents of adequacy and proponents of equality in educational opportunity reflects very different ways to think about just educational policy and practice. This paper is trying to address this debate. It proceeds as follows. In the next section, I will outline the Equality vs. Adequacy debate. Then, in section III, I would like to take issue with these approaches. I will argue that both approaches have negative effects on equality and justice in education. Finally, inspired by Harvard political philosopher Danielle Allen's work on education and equality, I will propose an alternative conception of educational equality. I believe it is a better way of understanding the meaning of educational justice for a democratic society.
\end{abstract}

Keywords: educational equality, educational adequacy, meritocracy, relational egalitarianisms, Danielle Allen

\section{Equality VS Adequacy}

Over the past decades, there has been ongoing philosophical debate between luck egalitarianism and relational egalitarianism regarding whether the conception of equality should be treated as distributional

Chun-Hung Chen, Ph.D., London School of Economics and Political Science (LSE), associate professor of Political Science, Soochow University, Taiwan; main research field: Contemporary Political Philosophy, Human Rights in Theory and Practice, Democratic Theory. 
equality or relational equality. For luck egalitarianism, equality ${ }^{1}$ is an essentially distributive value, and justice requires that we strive to achieve fully egalitarian distributions. Although luck egalitarians may differ in many respects, they generally share the view that inequality is permissible when it derives from people's voluntary choices but is unjust when it is the product of people's unchosen circumstances or luck (Scheffler 2015, 21). In this regard, the state ought to make up for morally arbitrary inequalities in order to express the state's equal concern and respect for its citizens. As Richard Arneson has indicated:

The concern for distributive justice is to compensate individuals for misfortune. Some people are blessed with good luck, some are cursed with bad luck, and it is the responsibility of society—all of us regarded collectively - to alter the distribution of good and evils that arises from the jumble of lotteries that constitutes human life as we know it... (Arneson 1989, 83)

By contrast, relational egalitarianisms conceive equality as an ideal governing certain kinds of interpersonal relationships. ${ }^{2}$ For relational equality, justice requires the establishment of a society of equals whose members relate to one another on an equal standing. The aim of egalitarian is to replace social hierarchies with relations of social equality on the ground that individuals are fundamentally moral equals. If equality is conceived as a relational ideal in this way, then its bearing on questions of distribution is indirect since the equal distribution of a good does not necessarily satisfy the demand for equal. For instance, "separate but equal" bathroom facilities for black and white people are still unequal even if the quality of facilities were equal because their function is to constitute black people an inferior race (Anderson 2012, 41). Thus, for relational equality, the relevant question is not "What is the currency of which justice requires an equal distribution?" but is rather, "What kinds of distributions are consistent with the ideal of a society of equals?" (Scheffler 2015, 22)

Recently, an equivalent debate about the meaning of equality is taking place in the sphere of education. According to the educational equality perspective, the education system should ensure that each individual has equally good educational opportunities. ${ }^{3}$ They argue that an unequal distribution of education is unjust because it leads to an unfair competition for social advantages (Brighouse 2010, 28). However, from the educational adequacy perspective, the education system should be set up at the adequate level in a way to ensure an adequate education for all. ${ }^{4}$ If it has done, educational inequalities above this level are not unjust (Anderson 2007). In the following, I will explicate these two views respectively. I will analyze this debate mainly draws on the contributions by Harry Brighouse, Adam Swift, Elizabeth Anderson, and Debra Satz, among others.

\section{Educational Equality}

\subsection{Meritocratic Conception of Equality}

According to educational equality perspective, the society is relevantly like a race (Brighouse and Swift 2014, 18). The distribution of the benefits of social cooperation is structured to reward to those who do well and penalize those who do badly in the competitions. Undoubtedly, educational attainment and achievement is associated with many different indicators of social success, inter alia, those who rank higher in educational achievement and attainment are more likely to obtain a well-paid job and to maintain the competitive advantage of the state's economy in a globalized world. In this regard, education has a strong instrumental value since it has enormous influence on individual prospects for a flourishing life. Moreover, it is clear that education (schooling), as a way to achieve a good job or to register at a good college, is a positional good (Reich 2013, 
58-59). A good is positional when its value to the holder is not only determined by how good it is in absolute terms, but also on how good it is compared to that of other people (Brighouse and Swift 2006, 474-5). Accordingly, education as positional goods which means that its absolute value for one person depends on how well educated she is relative to other persons. Just as Fred Hirsch argues "if everyone stands on tiptoe, no one see any better." What really matters is not how much education one gets, or how good that education is, but one's position relates to others in the distribution of education. Like a zero-sum game, if one has more, the other inevitably has less. Thus, any educational inequality is likely to disadvantage the worse off in the "race" for advantage. When one child gains unfair educational advantage, she would "jumps the queue," pushing other children back in the line and decreasing their chances to secure these socially desirable positions (Swift 2003). Thus, the argument for educational equality is that all children should be given a fair opportunity to compete for educational achievement.

What does the "fair competition" mean? It means that "merit" should dictate access to educational opportunity and not factors exogenous to merit. Thus, people with the same level of merit-IQ+effort should have equal chances of success (Swift 2003, 24). ${ }^{6}$ If some children are prevented from competing equally with others, through no fault of their own, the inequalities of the distribution that result are unjust. In this regard, children who have the same talent and motivation should bring up to the same level of achievement, no matter if they are rich or poor, white or black. As Brighouse and Swift clearly point out, an individual's prospects for educational achievements may be a function of that individual's talents and efforts, but they should not be influenced by her social class background (Brighouse and Swift 2014, 15).

\subsection{Legitimate Parental Partiality}

It goes without saying that many factors outside schools affect children's development. As James Coleman has indicated, "complete equality of educational opportunity can be reached only if all the divergent out-of-school influences vanish."7 However, some parents will provide vast educational opportunities to their children, while others will not. Therefore, the family's profound influence on a child's prospects which would result in the meritocratic conception of equality could not be completely achieved. However, following the meritocratic view of educational equality, the educational achievement of equality should require a great deal of interference with family life. Not only the state requires to bring children up the bottom by taking children away from educationally negligent parents, but also to level down the top by preventing parents from supplying extra educational advantages to their children.

For Brighouse and Swift, because family can produce valuable social goods, such as the goods that come with intimate relationships, it needs to strike a balance between parental liberty and educational equality. They think that parents do have a right to develop intimate relationships with their children, and this right would allow parents to spend a good deal of time with their children, and share their values and enthusiasms with their children, even if they would confer educational advantages on their children. These "relationship goods" are often important enough to protect, "despite their tendency to undermine fair equality of opportunity" (Brighouse and Swift 2009, 50). Any educational policy is flawed if "it would prevent most parents and children from spending the amount of time together needed in order for them to have rewarding and intimate relationships, which, we think, are among the most important human goods” (Brighouse and Swift 2009a, 124). In other words, they reject the meritocratic conception of education would always "trump" parental liberty. Thus, reading bedtime stories to children or accompanying to church with children is allowed and protected 
since it is an intimate activity even though it has a long-term impact on educational inequality. However, Brighouse and Swift doubt that parents have a counterbalancing right to invest their resources to secure a competitive advantage for their children. For instance, sending children to private school, or pay for your children to have a literature or math tutor, is not essential to establishing valuable family relationships and would undermine fair equality of opportunity.

Accordingly, parents' inequality-producing activities are justified only if they promote family intimacy “(a) when there are no other alternatives or (b) if they are the result of parents acting to enjoy time together rather than according to a systematized plan for future development” (Brighouse and Swift 2014, 24-25).

\section{Educational Adequacy}

\subsection{Relational Equality}

In contrast with meritocratic conception of educational equality to defend justice requires prospects for educational achievement to be dependent upon child's ability and willingness to learn, educational adequacy argues that justice calls for each person to be educated to a level adequate for the requirements for full citizenship in a democratic society. Once a minimum level of opportunity is available to all, then inequalities above this level are not unjust.

From the adequacy view, dispositions of democratic citizenship are linked to equal treatment in schools. Democratic citizenship involves learning to see oneself in a particular way, say, as an individual with equal standing among others. At this matter, academic experiences or the school one attends are very visible markers of one's status as a citizen, since variations in educational resources can create perceptions of first-class and second-class citizens, and can send hidden messages of civic inferiority (Warnick 2015, 3). Besides, being equal is not merely a matter of what we are or what we have, but of what we do, and so it too requires knowledge and skills. Schools should teach children how to be equal, in addition to teaching them that they are equal or what follows from their being equal (Landen 2013, 62). In this regard, schools have an important role to play in breaking down stereotypes and animosity between groups and in encouraging intergroup knowledge and understanding. Moreover, educational institutions must be constructed in a way that recognizes the dignity of citizens from diverse social, economic, ethnic backgrounds, and they must provide citizens with the knowledge, skills, and civic virtues that is responsive to the needs of a wide variety of peoples and social groups. For Anderson, thus, the members of elite must be drawn from all significant social groups and children from all walks of life should be educated together. Social integration within schools does not only enable bearers of elite position to gain the knowledge necessary for good decision making; it also makes it more likely that members of disadvantaged groups can join the elite themselves. As Anderson put it:

... I have argued that an elite qualified to serve a socially diverse society must be socially integrated, incorporating that diversity within itself not just in membership but in social interactions among its members. This means that the members of the elite must be drawn from all significant social groups and be educated together. Working backward from the requirements for a qualified elite, we can derive a standard of fair educational opportunity to which all social groups should be entitled. (Anderson 2007, 614)

\subsection{Sufficientarian Standard}

Furthermore, educational adequacy does not require that everyone has equal resources, or the level of education necessary to gain entry into the top excellent schools. To be a fully capable citizen, everyone requires 
a threshold level of knowledge and competence. Anderson claims it requires members of all social groups to have effective access to a primary and secondary education sufficient to qualify them for success at a four-year residential college with such a curriculum. Likewise, Satz lists five criteria by which primary and secondary education ought to be distributed in order to realize adequacy: secure an educational minimum necessary for acting politically and maintaining employment; secure fair opportunities for educational and employment positions above the minimum; secure the distribution of leadership skills among diverse social groups; develop the capabilities needed for cooperative interactions in a diverse society; and avoid leveling down the development of talent and ability through education, except insofar as this is necessary to get all children with the requisite potential above citizenship’s high threshold (Satz 2007, 647-8). It is sufficient which means that it doesn't need everyone to have equal resources or equal development of potential. As Anderson put it:

Sufficientarian principles do not constrain inequalities in educational access above the sufficiency threshold. Parents who want to provide their children with more education than the minimal required to enable them to complete successfully a serious four-year college degree are free to do so, using their own private resources or by demanding that their public schools provide more. The sufficientarian standard thus rejects "leveling down" educational opportunities to the lowest common denominator in the name of equality. I believe such leveling down ought to be rejected, because the development of human talents is a great intrinsic good, a good to the person who has it, and a good to others. More highly educated people are better able to serve others in demanding jobs and volunteer service positions. (Anderson 2007, 615)

It is clear to see that Anderson and Satz strongly disagree with Brighouse and Swift about the scope of the parental liberty principle. They think that parents have a right to use their own money to promote their children's education. As Satz has commented:

\begin{abstract}
Many parents want better education for their children-including private lessons-because they believe that education is intrinsically valuable, not because they want their children to be wealthier or more advantaged than their peers. Their commitment to education does not stem from the desire to help their children obtain competitive advantages in the job market but rather from their appreciation of the good of education for personal development. Or maybe they just don't want to see their children bored and unhappy in school. The Swift/Brighouse argumentum acceptably constrains those families with conceptions of the good that favor promoting the education of their child-but lack the time to do the promoting themselves. Dual-career families are likely to be especially constrained by their approach. (Satz 2007, 634)
\end{abstract}

In contrast with Brighouse and Swift, Anderson and Satz argue that when the adequate threshold of education resource is obtained, there is no injustice if parents want to provide more educational resources to their children.

\title{
4. The Critiques
}

If above-mentioned analysis is sound, then we can find that both views of educational justice face some theoretical problems. In terms of the view of meritocratic conception of educational equality to stress on the positionality of education and the permissibility of leveling down educational provision, it is clear that the meritocratic conception of educational equality is unable to be the aptly distributive principle for the public school. On the one hand, education is not a pure positional good. It is also intrinsically valuable to a flourishing life. These aspects of education make education a non-competitive good. Furthermore, it is wrong to use merit as a basis for evaluating the distribution of school resources, because "there is no preexisting merit that is relevant to the question of who deserved to go to college or get the best job" (Howe 2015). By contrast, the merit that matters in the case of employment and university access is "developed talent and ability," not innate talent and ability per se. In other words, talent is endogenous to social circumstances and its development is 
influenced by many factors, including early cognitive input, parental time, physical environment, and socialization, etc. Moreover, innate talent is arbitrary factor which lies beyond one's control as well as social class. Children cannot defensibly be responsible for their talents, and it is unfair to get an advantageous social position simply because of one's inborn talents. In this regard, natural talent cannot be perceived in individual cases, because "native endowments are not fixed, but merely potential and must be brought to fruition in the social world.” There would be no foundation for conceptualizing a just distribution of education in terms of a fair competition to bring natural talents to fruition (Howe 2015, 190). As Rawls clearly put it:

... native endowments of various kinds (say, native intelligence and natural ability) are not fixed natural assets with a constant capacity. They are merely potential and cannot come to fruition apart from social conditions; and when realized they can take but one or a few of many possible forms. Educated and trained abilities are always a selection, and a small selection at that, from a wide range of possibilities that might have been fulfilled. Among what affects their realization are social attitudes of encouragement and support, and institutions concerned with their early discipline and use. Not only our conception of ourselves, and our aims and ambitions, but also our realized abilities and talents, reflect our personal history, opportunities and social position, and the influence of good and ill fortune. (Rawls 2001, 57)

In terms of the critique of adequacy approach, it is clear that adequacy view requires a level of spending sufficient to satisfy some absolute, rather than relative, educational threshold. However, as mentioned previously, since education has positional aspect, it does matter that some children get better education than others, even if all children receive adequate education. When all students receive adequate education, there are no guidelines how to distribute any further available resources. If the inequalities that adequacy permits fail to integrate such privileged positions in universities and employment across class and racial lines, then adequacy is not adequate to its purpose (Satz 2007, 643). Therefore, stressing on the non-positional aspect of educational good but not constraining inequalities in educational access above the sufficiency threshold, it fails to be an adequate principle for democratic citizenship.

\section{Democratic Adequacy: A Preliminary Enquiry}

If above-mentioned critique is sound, in what follows, I would propose an alternative view of educational justice what I call it a "democratic adequacy conception of educational justice” $(2008,425) .{ }^{8}$ The scheme is based on the "humanistic baseline" conception of education inspired by Danielle Allen. Following that, it suggests a very different way to understand the link between education and equality.

Firstly, before talking about the distribution of educational goods, I argue that we cannot fully grasp the relation between education and equality without a clear grasp of what education fundamentally is. We should not reduce all instruction of educational system to training, or the cultivation of useful skills. Following Allen, I view education as fundamentally preparation for a flourishing life. What all the different educational institutions have in common, despite their different purposes, is the "aspiration to direct the development of human capacities” (Allen 2016, 20). As Allen points out:

In order to count as education, the practices sponsored by those institutions need to further the development of an individual qua human being-namely, a creature whose flourishing entails the development of a range of valuable cognitive, affective, and intersubjective capacities. I refer to this as the humanistic baseline for the concept of education. (Allen 2016, 21)

Rather than based on a vocationally oriented frame of global competiveness and on innovative human capital, this humanistic conception of education is based on the social practice of human development. As Allen put it: 
The activity of educating and also the techniques developed to pursue teaching and learning are identified by a single end: cultivating human development. This is true even when a student chooses a vocational training course for the sake of making money. In order for that training to succeed, it must still affect the development of student qua human being-for that is what it means for any of us to cultivate capacities and abilities. (Allen 2016, 18)

Instead of seeing education as only contributing to economic equality, thus, Allen proposes that education should aim equalizing civic engagement through "participatory readiness" (Allen 2016, 35). It is not only the development of skills for competing in the global marketplace but also the development of skills and dispositions for creating an informed and engaged citizenry.

But what is participatory readiness? What kind of education can help students to achieve? Following Hannah Arendt, Danielle Allen proposes a conception of citizenship to be "the activity of co-creating a way of life, of world-building.” This conception of citizenship (civic agency) which Allen is trying to defend involves three core tasks: disinterested deliberation, frame shifting, and fair fighting. As Allen has indicated:

Such civic agency involves three core tasks. First is disinterested deliberation around a public problem. Here the model derives from Athenian citizens gathered in the assembly, the town halls of colonial New Hampshire, and public representatives behaving reasonably in the halls of a legislature. Second is prophetic work intended to shift a society's values; in the public opinion and communications literature, this is now called "frame shifting." Think of the rhetorical power of nineteenth-century abolitionist Harriet Beecher Stowe, of Martin Luther King, Jr., or of Occupy Wall Street activists with their rallying cry of "we are the 99 percent." Finally, there is transparently interested "fair fighting," where a given public actor adopts a cause and pursues it passionately. One might think of early women's rights activists such as Elizabeth Cady Stanton, Susan B. Anthony, and Matilda Joslyn Gage. (Allen 2016, 43)

For Allen, the conception of civic agency here defines not only our preparation for civic and political life, but it also undergirds our preparation in all the areas in which we hope to prosper. When young people leave school or college, we hope that they are prepared to participate effectively at work in a neighborhood; in a networked community or association; in a city, state, or nation; even at a global scale (Allen 2016, 35).

Following Allen's conception of education as fundamentally preparation for a flourishing life, the aim of education in my scheme is to develop not only vocational capacities, but also civic agency. Simply put, it is not a commodity, but is "the awakening of a human being"9 (Rawlings 2015). Therefore, the preparation for capable citizenship is a primary purpose of education in this scheme. Schools should help young people acquire and learn to use the skills, knowledge, and attitudes that will prepare them to be competent and responsible citizens throughout their lives. As Rawls has said:

The state's concern with their educational lies in their role as future citizens, and so in such essential things as their acquiring the capacity to understand the public culture and to participate in its institutions, in their being economically independent and self-supporting members of society over a complete life, and in their developing the political virtues. (Rawls 2001, 57)

Moreover, as John Dewey has indicated, “democracy has to be born anew every generation, and education is its midwife.” It means that democracy is an on-going process that needs constant attention, nurturing and renewal. Thus, education was critical to a democratic society. Empirical evidences have shown that education is a causal force behind democracy. For instance, economists Edward L. Glaeser, Giacomo Ponzetto, and Andrei Shleifer argue that education fosters participation because it prepares people for democratic engagement. Reading, writing, and collaboration are the basic instruments of political action (Glaeser et al. 2006). Accordingly, state must educate students for college, career, and citizenship (3C). Civic readiness is 
the essential "third C" in a democracy (Levinson 2012b). In this regard, it requires providing students with an education that provides them not only with college and career readiness but also with "participatory readiness" or "civic readiness," inter alia, preparation to participate in their communities, their states, and the nation's political institutions. What competent and responsible citizens need are civic knowledge, skills, attitudes, and behaviors. They need to be knowledgeable about politics, history, government, and current events; they need to be skilled communicators, thinkers, deliberators, and actors; they need to be concerned about the common good in addition to their own self-interest, and to believe it is possible and worth trying to make a difference through public action; and they need to become involved in public or community affairs, through some combination of voting, protesting, contacting public officials, mobilizing others, contributing time or money to causes or campaigns, participating in community groups, and other appropriate actions (Levinson 2010, 335). Civic learning opportunities are thus essential for promoting civic equality as a democratic ideal (Levinson 2011, 18). Without civic knowledge, skills, identity, and propensity toward engagement, some students are essentially disenfranchised and disempowered. For instance, American political philosopher Meira Levinson has outlined a “... profound civic empowerment gap... between ethnographical minority, naturalized, and especially poor citizens, on one hand, and white, native-born, and especially middle-class and wealthy citizens on the other” and it was proved that this gap is caused or exacerbated by the current American education system because it fails to develop the civic knowledge, skills, and dispositions necessary for full participation in democratic life. Furthermore, she found that there is a closer correlation between level of educational attainment and likelihood of voting than even between socioeconomic status and likelihood of voting (Levinson 2012a, 38). It turns out that educational attainment is a better predictor of the likelihood of voting than even income. As a result, those disadvantaged are unlikely to become active participants in civic and political life and are unlikely to influence civic and political deliberation or decision-making in the future. Other empirical evidence has also shown that political influence seems to be limited entirely to affluent and middle-class people, and the views of ordinary citizens seem to have had very little impact on public policy at American democracy ${ }^{10}$ (Bartels 2008, 5). However, we cannot be said to live in a true democracy if individuals or members of groups systematically possess unequal civic and political power, if some votes and voices count more or less than others, or if some stand either above or below the law (CIRCLE 2003, 18). This civic empowerment gap thus weakens the quality and integrity of democracy. At this matter, Levinson argues that public schools have a responsibility to help citizens overcome both attacks on democracy and civic equality. It is imperative that schools should make certain that all students have access to high-quality civic learning opportunities throughout their education to combat the civic empowerment gap.

Following that, in terms of the distribution of educational resources, it is necessary to have a threshold based on what is needed for citizens to participate in a democratic society. I argue we need a democratic threshold that is based on the knowledge, skills, and dispositions necessary to participate in democratic processes, namely, participatory readiness. The basic skills, knowledge, dispositions, and ideas necessary for democratic citizenship are not positional. It is an outcome-based principle of democratic threshold since some degree of educational achievement is simply necessary for students to act as citizens, not the reward of the competition. This is a precondition that has to be fulfilled for the aim of educational equality. We need a democratic threshold for giving more resources to disadvantaged students up to the point of the democratic threshold, and helping all capable students to a certain level of attainment. If the goal of educational system is to achieve participatory readiness for all students, then civic achievement gap means we are not doing 
well enough in cultivating "participatory readiness" in our educational system (Allen 2016, 52). Following the conception of civic agency mentioned previously, moreover, we need the resources to aim our pedagogic and curricular work to bring out these capacities for civic agency. ${ }^{11}$

In this regard, the democratic adequacy threshold can minimize "the levelling down objection.” It can stop engaging in an unending "arms race" with wealthier parents, and provide legitimately extra resources to disadvantaged students. The threshold is defined in terms of the level and kind of education required to foster the kind of equal status as a citizen associated with the ability to effectively engage in civic and political life.

Moreover, once the threshold has reached, the disadvantaged students have achieved the skills, dispositions, and knowledge for equal citizenship, we should pay attention to the gap between the least advantaged and the most advantaged and to ensure it is not so great to undermine the conditions for equal citizenship. That is, my democratic adequacy scheme does not require in the equal distribution of resources, but the level of permissible inequality is significantly constrained by the requirement of equal citizenship. Citizens are not equals when there is a closed intergenerational social elite with disproportionate access to society's positions of political and economic power. When some social groups are excluded from competing for positions of advantage or economic wealth, they are in fact relegated to second-class citizenship, even if they meet the threshold. Accordingly, we should ensure the gap between the least advantaged and the most advantaged is not so great that it undermines the conditions for equal citizenship.

In sum, my scheme of democratic adequacy has egalitarian and relational elements. It is egalitarian which means that democratic adequacy conceives educational justice in terms of civic and political equality. In contrast to meritocratic conception of educational equality that emphasizes its position relative to other goods, the democratic adequacy closely ties education to democracy. In contrast to educational adequacy perspective, my modified version of democratic adequacy seeks to put people into democratic relationship as equal citizens, and thus the level of inequality in resources and opportunities is constrained to the extent required to achieve this aim.

If we choose civic agency as our orienting ideal-empowering all to participate capably in the life of a polity, then a different view of education's purpose, content, and consequence comes into view. My modified version of democratic adequacy seems to give proper reason for putting educational justice in its place.

\section{Notes}

1. For instance, Richard Arneson, “Equality and Equal Opportunity for Welfare,” Philosophical Studies 56 (1989): 77-93; Richard Arneson, "Luck Egalitarianism and Prioritarianism,” Ethics 110 (2000): 339-49; Richard Arneson, "Luck Egalitarianism: A Primer,” Responsibility and Distributive Justice, 2010. Eds. Carl Knight and Zofia Stemplowska. Oxford University Press; Ronald Dworkin, 2000, Sovereign Virtue: The Theory and Practice of Equality. Cambridge, MA: Harvard University Press; Ronald Dworkin, "Equality, Luck and Hierarchy," Philosophy and Public Affairs 31 (2003): 190-8; Gerald A. Cohen, 2000, If You're an Egalitarian, How Come You're So Rich? Cambridge, MA: Harvard University Press; John Roemer, 1994, Egalitarian Perspectives: Essays in Philosophical Economics. New York: Cambridge University Press; Kok-Chor Tan, 2008, “A Defense of Luck Egalitarianism,” The Journal of Philosophy CV/11: 665-90.

2. For instance, Elizabeth Anderson, "What Is the Point of Equality?” Ethics 109 (1999): 287-337; "What Is Egalitarianism?” Philosophy and Public Affairs 31.1 (2003): 5-39; Samuel Scheffler, "Choice, Circumstance, and the Value of Equality," Philosophy, Politics, and Economics 4 (2005): 5-28; Jonathan Wolff, "Fairness, Respect, and the Egalitarian Ethos.” Philosophy and Public Affairs 27 (1998): 97-122; Iris Young, 1990. Justice and the Politics of Difference. Princeton, NJ: Princeton University Press; Christian Schemmel, "Luck Egalitarianism as Democratic Reciprocity? A Response to Tan,” The Journal of Philosophy 
109 (2012): 433-48; Christian Schemmel, “Distributive and Relational Equality,” Politics, Philosophy and Economics 11 (2012): $123-48$.

3. For instance, Harry Brighouse and Adam Swift, "Equality, Priority and Positional Goods,” Ethics 116.3 (2006): 471-97; Harry Brighouse and Adam Swift, "Parents' Rights and the Value of the Family,” Ethics 118 (2006): 80-108; Harry Brighouse and Adam Swift, "Putting Educational Equality in Its Place," Education Finance and Policy 4 (2008): 444-66; Harry Brighouse and Adam Swift, "Educational Equality versus Educational Adequacy: A Response to Anderson and Satz," Journal of Applied Philosophy 26.2 (2009): 117-28; Harry Brighouse and Adam Swift, "Legitimate Parental Partiality,” Philosophy \& Public Affairs, 1 (2009): 49-80; Harry Brighouse and Adam Swift, 2014, "The Place of Educational Equality in Educational Justice,” 14-33, in Kirten Meyer (ed.), Education, Justice and the Human Good. Routledge; William. S. Koski and Rob Reich, "When Adequate Isn't: The Retreat from Equity in Educational Law and Policy and Why It Matters,” Emory Law Review 56.3 (2007): 545-618; and Rob Reich, 2013, "Education, Adequacy, and K12 Education," 43-61, in Danielle Allen and Rob Reich (eds.), Education, Justice and Democracy, University of Chicago Press.

4. For instance, Amy Gutmann, 1989, Democratic Education, Princeton University Press; Jame Tooley, 1996, Education without the State, London: IEA; Elizabeth Anderson, 2004, "Rethinking Educational Opportunity: Comment on Adam Swift's How Not to Be a Hypocrite," Theory and Research in Educatio: 99-110. Elizabeth Anderson, "Fair Opportunity in Education: A Democratic Equality,” Ethics 117 (2007): 595-622; Elizabeth Anderson, 2012, Equality, 40-57 in David Estlund (ed.), Oxford Handbook of Political Philosophy. Oxford University Press; Debra Satz, "Equality, Adequacy, and Education for Citizenship," Ethics 117.4 (2007): 623-48; and nd Debra Satz, 2008, "Equality, Adequacy, and Educational Policy,” Education Finance and Policy 3(4): 424-43.

5. Hirsch, Fred. 1976, Social Limits to Growth. Cambridge, MA: Harvard University Press.

6. John Rawls made a similar point when he indicated "... those with the same level of talent and ability and the same willingness to use those gifts should have the same prospects of success regardless of their social class of origin” ( Rawls 2001, 44).

7. James Coleman, 1968, “The Concept of Equality of Educational Opportunity,” Harvard Educational Review Vol. 38, 7-22.

8. Actually, Debra Satz has argued that her conception of adequacy is deeply rooted in a concern for civic equality. As she says: "On my view, a certain type of equality — civic equality-is actually internal to the idea of educational adequacy for a democratic society” (2008, 425). Inspired by her argument, my modified version is deeply rooted in a concern for civic and political equality.

9. Hunter Rawlings, 2015, College is not a commodity. Stop treating it like one, Washington post, June 9.

10. Indeed, political scientists have known for a very long time that higher levels of educational achievement map directly onto higher levels of civic knowledge, skills, and engagement (vebra, Schlozman and Brady, 1995).

11. Furthermore, Allen proposes that the work of humanities and social sciences on verbal empowerment and social analysis is intrinsically related to the development of participatory readiness.

\section{Works Cited}

Allen, Danielle. Education and Equality. Chicago: University of Chicago Press, 2016.

---. "What Is Education for." Boston: Boston $<$ https://bostonreview.net/forum/what-education/clint-smith-clint-smith-responds-danielle-allen>.

Anderson, Elizabeth. "Fair Opportunity in Education: A Democratic Equality.” Ethics 117 (2007): 595-622.

---. “Equality.” Ed. David Estlund. Oxford Handbook of Political Philosophy. Oxford: Oxford University Press, 2012. $40-57$.

Arneson,Richard. "Equality and Equal Opportunity for Welfare.” Philosophical Studies 56 (1989): 77-93.

Brighouse, Harry. "Educational Equality and School Reform.” Eds. Harry Brighouse, James Tooley, and Kenneth R. Howe. Educational Equality. Graham Haydon, Second Edition, Continuum, 2010, 15-69.

Brighouse, Harry and Adam Swift. "Equality, Priority and Positional Goods.” Ethics 116.3 (2006): 471-97.

---. "Parents’ Rights and the Value of the Family.” Ethics 118 (2006a): 80-108.

---. "Putting Educational Equality in Its Place.” Education Finance and Policy 4 (2008): 444-66.

---. "Educational Equality versus Educational Adequacy: A Response to Anderson and Satz.” Journal of Applied Philosophy 26.2 (2009a): 117-28.

---. “Legitimate Parental Partiality.” Philosophy \& Public Affairs 1 (2009b): 49-80.

---. “The Place of Educational Equality in Educational Justice.” Ed. Kirsten Meyer. Education, Justice and Human Good. NY: Routledge, 2014. 14-33.

Carnegie Corporation of New York and CIRCLE. “The Civic Mission of Schools.” New York: Carnegie Corporation of New York and CIRCLE, 2003.

Glaeser, Edward L, Giacomo AM Ponzetto, and Andrei Shleifer. “Why Does Democracy Need Education?” Journal of Economic Growth 12.2 (2007): 77-99. 
Gutmann, Amy. Democratic Education. Princeton, NJ: Princeton University Press, 1987.

Howe, Kenneth. "The Meritocratic Conception of Educational Equality: Ideal Theory Run Amuck.” Education Theory 65.2 (2015): 183-201.

Koski, William S. and Rob Reich. "When Adequate Isn't: The Retreat from Equity in Educational Law and Policy and Why It Matters.” Emory Law Review 56.3 (2007): 545-618.

Levinson, Meira. "The Civic Empowerment Gap: Defining the Problem and Locating Solutions.” Handbook of Research on Civic Engagement. Eds. Lonnie Sherrod, Judith Torney-Purta, and Constance A. Flanagan. Hoboken, NJ: John Wiley \& Sons, 2010. 331-61.

---. No Citizen Left behind. Cambridge: Harvard University Press, 2012a.

---. “The 'Third C’: College, Career, and Citizenship.” Making Civics Count: Citizenship Education for a New Generation. Eds. David E. Campbell, Meira Levinson, and Frederick M. Hess. Cambridge, MA: Harvard Education Press, 2012b. 247-58.

Rawls, John. Justice as Fairness: A Restatement. Cambridge, MA: Harvard University Press, 2001.

Reich, Rob. "Education, Adequacy, and K12 Education.” Eds. Danielle Allen and Rob Reich. Education, Justice and Democracy. Chicago: University of Chicago Press, 2013. 43-61.

Satz, Debra. "Equality, Adequacy, and Education for Citizenship.” Ethics 117.4 (2007): 623-48.

---. "Equality, Adequacy, and Educational Policy.” Education Finance and Policy 3.4 (2008): 424-43.

Scheffler, Samuel. “The Practice of Equality.” Eds. C. Fourie, F. Schuppert, and I. Wallimann-Helmer. Social Equality: Essays on What It Means to Be Equals. Oxford: Oxford University Press, 2015. 21-44.

Swift, Adam. How Not to Be a Hypocrite: School Choice for the Morally Perplexed Parent. London: Routledge, 2003.

Warnick, Bryan R. “Taming the Conflict over Educational Equality.” Journal of Applied Philosophy 32.1 (2015): 50-66. 